\title{
An evaluation of the hydrogeology potential of Nsukka, Southern Nigeria, using geographic information system
}

\author{
Mkpuma Rock Onwe ${ }^{1}$ (1) $\cdot$ Ema Michael Abraham ${ }^{1} \cdot$ Ngwu Tochukwu Ambrose $^{1} \cdot$ Osibe Kingsley Osike $^{2}$
}

Received: 28 December 2019 / Accepted: 21 January 2022 / Published online: 28 February 2022

(c) The Author(s) 2022

\begin{abstract}
Groundwater potential has been adjudged a panacea to residential development and livelihood improvement. Negligence to its spatio-heterogeneity over an area of concern leads to mismatches, i.e. land use misappropriation. Pumping test data from 26 boreholes were used to produce both static water level and hydraulic head with static water level range of $221.6 \mathrm{~m}$ in Ede-oballa to $66.6 \mathrm{~m}$ in Obimo, while hydraulic head varies from 182.1 to $322.04 \mathrm{~m}$ in Okpuje and Opi, respectively. Elevation values range from $251 \mathrm{~m}$ in Okpuje to $536 \mathrm{~m}$ in Ede-Oballa. Using ArcGIS the thematic maps of static water level, hydraulic head and elevation were interpolated and simulated to generate groundwater potential distribution. The resultant groundwater potential indices were delineated and its capability evaluated. Result indicates that these have control or influence on groundwater potential. The map models produced in this study provide better understanding towards proper management and utilization of groundwater resources in the Nsukka region.
\end{abstract}

Keywords GIS · Groundwater potential $\cdot$ Heterogeneity $\cdot$ Hydraulic head $\cdot$ Residential development $\cdot$ Mismatches $\cdot$ Static water level

\section{Introduction}

Nsukka is globally known because it plays host to one of the foremost Universities in Nigeria. In view of this, people from different parts of the world are residing there. Following a Nigerian adage "Water is Life", which means water is a critical factor to life on earth, it is pertinent, and therefore, to understand the groundwater potential in an area, since it is the most reliable and sustainable water source (Singh et al. 2018). Moreso considering groundwater potential geospatial distribution importance to factor of safety and

Mkpuma Rock Onwe

mkpuma.onwe@funai.edu.ng; onwerocky@ gmail.com

Ema Michael Abraham

emaabraham@yahoo.ca

Ngwu Tochukwu Ambrose

tochukwuambrose@gmail.com

Osibe Kingsley Osike

koosibe@fuwukari.edu.ng

1 Federal University Ndufu-Alike Ikwo (FUNAI NG), Abakaliki, Nigeria

2 Federal University Wukari, Wukari, Nigeria domestic water supplies for the teeming populace. Furthermore, development especially for residential quarters takes after closeness to and availability of water sources. Following the United Nations Sustainable Development Goals (SDGs), water plays a major role in livelihood (healthcare, poverty and environment); hence, its shortage is always a severe problem to mankind. Understanding the groundwater potential and its development is thus a major factor for economic growth as well as human and environmental health, and poverty reduction. Problems associated with lack of adequate water supply threaten to place the health of people at risk (Anukam 1997).

In Nsukka area, there is scarcity and difficulty in obtaining groundwater hence the need for a detailed investigation of groundwater resources and aquifer conditions of the area. Such investigation will provide an exploration guide as well as a suitable groundwater management strategy. To understand the groundwater potential in an area also involves studying the underlying geology because they are naturally inseparable and never homogeneous; hence, there is growing interest in the study of their geospatial variation using geoinformatics. This technique is yet well developed, but successful in characterizing the spatial variations of subsurface and groundwater (Liu et al. 2006; Onwe et al. 2019). Many 
authors have applied different methods for the evaluation and delineation of groundwater potential for the purpose of better management of the resource (Kaur et al. 2020; Singh et al. 2018). Generally, the methods of studying groundwater can be either practical or theoretical, (Toth 1963). Nevertheless, geospatial techniques have proved effective in identifying groundwater zones (Singh et al. 2018) as well as other capability indices. It provides the baseline information on factors controlling potentialities of resource (Akbas 2014). It is also an important determinant to efficiency and management. Nwankwor et al. (2004) and Onunkwo et al. (2011) determined geological parameters using analytical manual overlay and GIS approach, respectively, to index land use. Agarwal and Garg (2015) used remote sensing (RS) in conjunction with geographic information system (GIS) and multi-criteria decision-making techniques to delineate the groundwater potential and recharge zones. Kaur and Rishi (2018) and Singh et al. (2018) attempt to analyze the spatio-temporal variability of groundwater level and potential using integration of geospatial, geostatistical, RS, analytic hierarchy process (AHP) and Catastrophe theory approach. Thapa et al. (2017) reveal using well yield model to predict groundwater potential in a zone. Similarly, geospatial variation is an index to predicting groundwater potential. Integration of remotely sensed data and GIS methods is widely applicable in groundwater mapping (Kaur and Rishi 2018). One important way to gather this knowledge is to undertake geostatistical and soil baseline survey, prepare each factor with a common georeferenced thematic map and through spatial integration by interpolation and simulation in a GIS platform.

Understanding spatial variation of groundwater potential precisely will assist in proper environmental planning, drastically reduce mismatching and avert consequent geoenvironmental hazards (environmental damage, deterioration, geohazards such as earthquake, structural failures, landslide and soil creep, including flooding, erosion, groundwater contamination/pollution) that arise due to land capability index mismatching, (Onwe et al. 2018). Also, assessment of rock and soil properties' spatial variance is important for evaluating geoenvironmental resource vulnerability to impairment (Iňigo et al. 2012; Onwe et al. 2017).

Groundwater is a priceless part of fresh water supply; its availability can be influenced by either climatic or geologic conditions operating in the region. The knowledge of its geospatial distribution is fundamental in understanding the nature of the sources background, interactions within a region and its implications. Areas or zones of abundant groundwater availability are referred to as areas of enough groundwater potential. This is the total amount of permanent storage that exists in the aquifer of the area which is a function of the porosities of the rocks and amount of interconnectedness of the open space in the rocks that could store and transmit water. The hydraulic characteristic of an aquifer such as porosity and permeability as well as chemical contents of the groundwater determines the availability and suitability of groundwater resource for both use and development. A combination of ideas derived from hydraulic potentials and the static water level will enhance knowledge on groundwater resources of an area to a regional extent. The search for groundwater requires detailed geophysical investigations (Adepelumi et al. 2013), and employing the data acquired in a GIS platform infers the distribution (Ibeh 2020). Sustainable Development Goals (SDGs) and smart city agenda, it is important to know the limitations of a land; the uses it is capable of supporting and how susceptible a land is to geohazards such as erosion and contamination influences. This study is focussed on assessing the groundwater potential distribution of the Nsukka area using static water level, hydraulic heads and GIS methods for a better understanding and proper management and utilisation of ground water in the region.

\section{Study area}

The study area lies within latitudes $6^{\circ} 36^{\prime}-7^{\circ} 00^{\prime} \mathrm{N}$ and longitudes $7^{\circ} 16^{\prime}-7^{\circ} 30^{\prime} 30^{\prime \prime} \mathrm{E}$ with an undulating topography of elevations ranging from $301.5 \mathrm{~m}$ at AkutalaObimo to $534.5 \mathrm{~m}$ at Ede-oballa, Fig. 1. The area is within the Anambra basin of Southeastern Nigeria.

The Nsukka area consists of three major geologic Formations which comprises of the Mamu, Ajali and Nsukka Formations, (Ezeh and Ugwu 2010), Fig. 2.

The area also comprises of two hydrostratigraphic aquifers namely the upper Maastrichtian Nsukka Formation and middle Maastrichtian Ajali Sandstone both having similar hydraulic characteristics and lithology at depth, where regional saturation occurs, (Amah et al. 2016).

The Nsukka area, geologically, lies within the Anambra Basin; an inland sedimentary basin sandwiched between the Southwestern part of the Benue Trough and the Petroliferous Niger Delta (Ezim et al. 2017). A slow subsidence followed by a major regression led to the deposition of the Mamu (coal-bearing) and Ajali Formations which accumulated during the Maastrichtian. The Ajali Sandstone has been attributed to fluvial deposition, and the development of shallow marine sub-tidal sand bars (Ladipo 1986; Nwajide 2006). The Ajali identified as a false bedded sandstone overlies the Mamu Formation (Obi 2000) and consists of unconsolidated, poorly sorted, coarse-fine-grained sandstone, poorly cemented mudstone and siltstone, with a thickness of $300 \mathrm{~m}+$ (Egboka 1983) with cross-beddings as the dominant sedimentary structure of the Formation. It is associated with reactivation surfaces, mud drapes, tidal bundles, backflow ripple channels, cut and fills, lateral accretion surfaces, as well as Skolithos and Ophiomorphaichno genera (Ladipo 
(a)

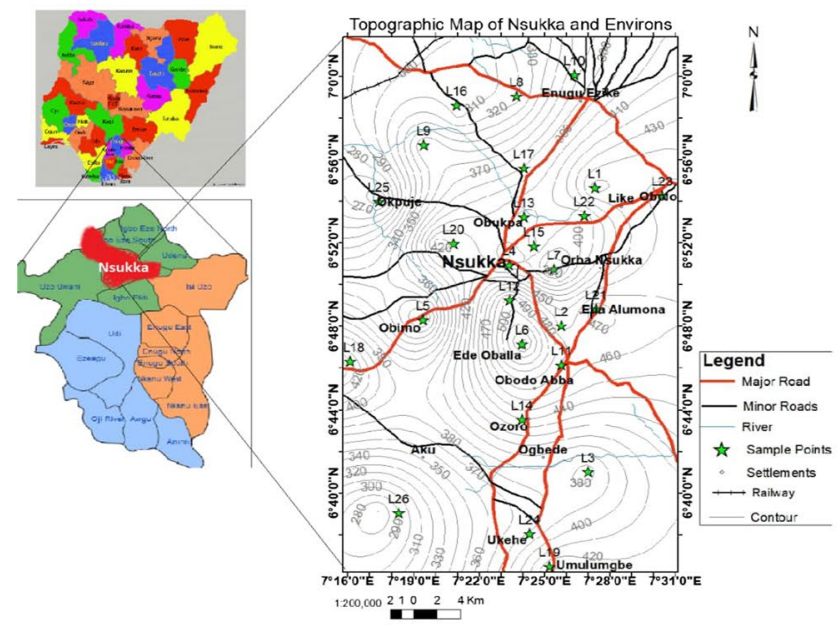

(b)

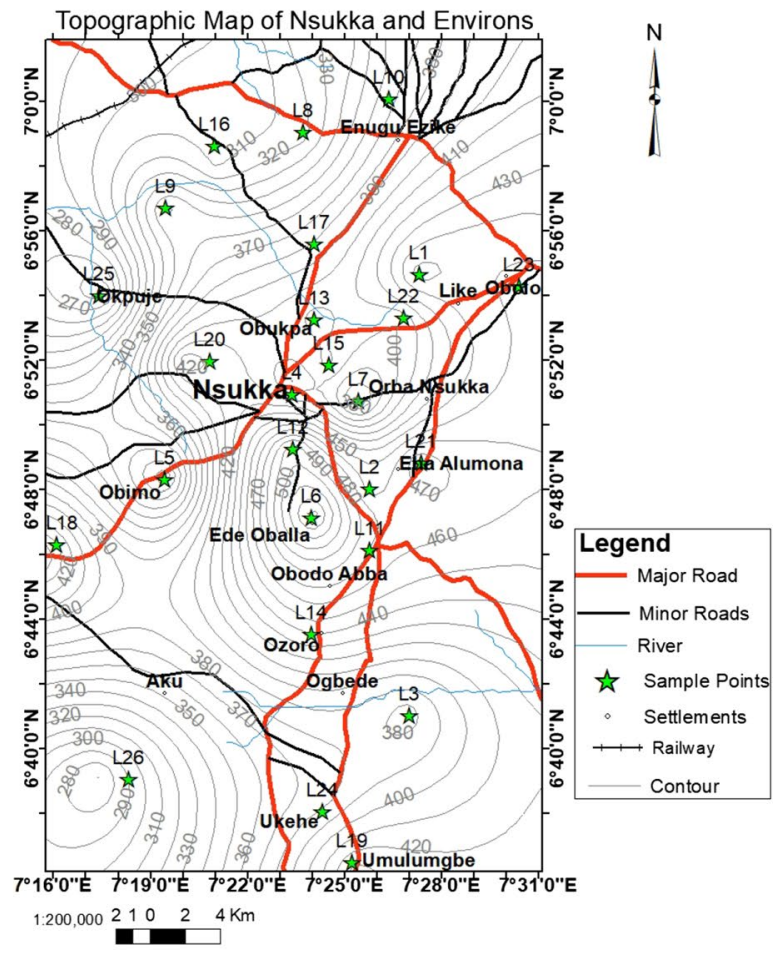

Fig. 1 a Physiographic map of Nsukka and environs. b Physiographic map of Nsukka and environs with sample points

et al. 1992). According to Uzoegbu et al (2013), the Formation is slightly diachronous, ranging from Middle to late Maastrichtian from South to North, and consists of mineralogically supermature, medium to coarse grained, moderately sorted quartz arenites. The Ajali Formation is well displayed along the lowland and dry valley zones of the study area including: Ede-Oballa, Obukpa, Onuiyi Road, Ibagwa Road, Obollo Road, Base of the Physics observatory, Odim area, and beyond Zik's flat (Ezim et al. 2016). The depositional environment of the Ajali Sandstone has been described as fluvio-deltaic depositional environment (Ladipo 1986).

The Nsukka Formation also known as the Upper coal measures conformably overlies the Ajali Sandstone (Reyment 1965; Obi 2000) which comprises of interbedded shale, siltstone, sand and thin coal seams with its beds generally gently dipping (amount of dip ranging from 1 to 6 degree). The Formation is diachronous, spanning upper Maastrichtian into Danian. Depositional environment has been suggested to be similar in many ways to the Mamu Formation (Lower Coal Measures), i.e. transitional/shoreline, mud flat and swamps, deposited during a largely regressive phase (Uzoegbu et al. 2013), while the eroded remnants of this Formation constitute outliers and its thickness averages $250 \mathrm{~m}$ (Ezim et al. 2017). The borehole data in the southern parts of the Anambra Basin used in the reconstruction of the stratigraphic unit reveal that the Formations (i.e. Mamu, Ajali and Nsukka) all appear to be steeply inclined and dipping towards the western flank of Onitsha High, and flattening out below the Imo Formation (Ezim et al. 2017).

\section{Topography, relief and drainage}

The study area shows two major types of landforms which comprises of a high relief zone with undulating residual hills, valleys and the lowland areas. The residual hills are the remnants of the Nsukka Formation which constitute the surface layers (Ezeh and Ugwu 2010). These layers are highly weathered and eroded and overlie the Ajali Sandstone. Ofomata (1967) had identified five types of these residuals according to their shapes: dome, conical, ridges, flat-topped or 'mesa-like' and 'cuesta-like'. The dry valleys are wider, flat-bottomed and spread all over the surface of the plateau. The dry valleys and the residual hills form an extensive escarpment referred to as the Nsukka-Okigwe Cuesta (Ezim et al. 2017). The lowlands are most profound in the northwestern part of the study area and serve as the collecting centre of the run offs during the rainy season. The drainage pattern in the area may furnish one with the outflows from the aquifer or recharge/inflow from outside the system. The drainage also furnishes one with the catchments of the aquifer system or indicates surface water/groundwater divides (Amah 2006), while surface drainage is very sparse in the central and much of the western area. Only one river 


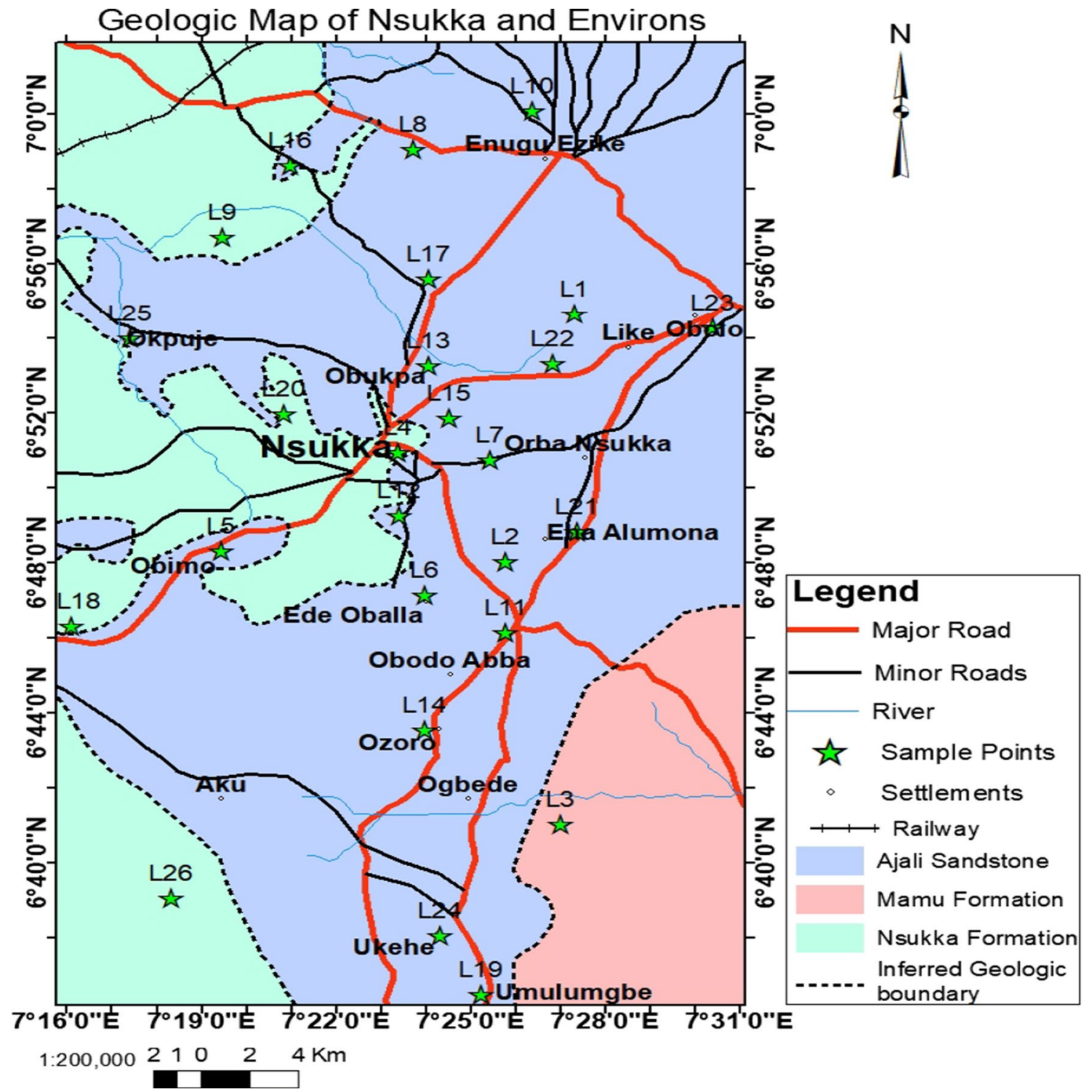

Fig. 2 Area and geologic map of Nsukka showing the three major lithostratigraphic units

(River Adada) crosses the Nsukka Plateau near Lejja (Ozoko 1996).

\section{Hydrogeology}

Nsukka area comprises of two hydrostratigraphic aquifer units, namely: the Upper Maastrichtian Nsukka Formation and Middle Maastrichtian Ajali Sandstone both having similar hydraulic characteristics and lithology. Generally, the basal shale unit of Nsukka Formation and upper limit of Mamu Formation confined the Ajali waters (Uzoije et al. 2014). According to Amah et al (2016), groundwater flow in Nsukka area is topography-driven with regional flow essentially from east to west, while the eastern portion of the study area comprising Ohodo, Opi, Ede Oballa,
Eha-Alumona constitutes the groundwater divide. Two flow systems were identified which comprises of the Upper system resulting from the overlying Nsukka Formation and the regional system starts from the groundwater divide in the east at a potential value of about $323 \mathrm{~m}$. According to Ugwuanyi et al (2015), Nsukka Formation has a significant groundwater potential and hosts a number of low to moderate yield wells. A number of perched aquifer emerges from it and quite a number of low yield wells also tap the perched aquifer in Nsukka areas (Ezeigbo and Ozioko 1987). The laterite capping in the area is aquiferous due to their vesicular nature; hence, it is porous and permeable. These lateritic caps are underlain by a less pervious clay beds leading to the formation of perched aquifer in some areas, and the discharge is seen in areas like the Asho hill in Nsukka, Aku hill 
in Obukpa, Abile hill in Ibagwa-aka and Awula in IbagwaAni (Ugwuanyi et al. 2015). The Ajali Sandstone aquifer is essentially unconfined in most of the areas (Ezim et al. 2017). Results of geoelectric resistivity surveys (Onwuemesi 1990) and static water level measurements in the relatively shallow boreholes near the crest of the escarpment indicate that the water table lies at a depth of about $55 \mathrm{~m}$ with a saturated thickness of the aquifer of about $85 \mathrm{~m}$ (Ezim et al. 2017) and a permeability of 2.0-20.7 $\times 10^{-10} \mathrm{~cm} / \mathrm{s}$ (Mamah and Ekine 1989). According to Uma et al. (1989), this Formation is regarded as a first class aquifer group. The Sandstone is very permeable and readily recharged in its outcrop belt around the Idah-Nsukka- Enugu escarpment (Agagu et al. 1985). Zones with aquifer thickness $>25 \mathrm{~m}$ with low clay content are zones with high groundwater potential which is about $88 \%$ of the study area, while zone with thickness ranging between 10-25 m has moderate groundwater potential with moderate clay content and that is obtainable in Amaogbo (Ugwuanyi et al. 2015). Aquifer thickness is variable, increasing from the east and northwest to the central part of the study area. Aquifer resistivity also shows similar trend in the area (Ezeh and Ugwu 2010). More so, transmissivity distribution in the area shows similar trend with the highest value of $2423 \mathrm{~m}^{2} /$ day at Ede-Oballa-Opi, thus suggesting high-quality reservoir within the area and it is evident that higher transmissivity area expected in areas underlain by the Ajali Formation (Ezeh and Ugwu 2010). Nsukka Formation has a significant groundwater potential and hosts a number of low to moderate yield wells in Nsukka areas and a number of perched aquifer emerges from it and quite a number of low yield wells also tap the perched aquifer in Nsukka areas (Ezeigbo and Ozioko 1987).

\section{Climate and weather}

The Nsukka area lies within the rainforest belt of Nigeria with the rainy and dry seasons. The dry season runs through the months of November to March, and the rainy season from April to October with a short period of reduced rains in August commonly referred to as "August break" (Ezim et al. 2017). The dry season also has Harmattan patches of dry cold hazy air. The area is also characterized by moderate temperatures and high relative humidity of about 80 to $90 \%$, with annual rainfall of $986 \mathrm{~mm}-2,098 \mathrm{~mm}$ during the rainy season, while the dry period is characterized by high temperatures and lower relative humidity ranging from 50 to $80 \%$. The mean temperature value ranges from $22{ }^{\circ} \mathrm{C}$ to $35^{\circ} \mathrm{C}$, with daytime range of 17 to $28^{\circ} \mathrm{C}$; with the mean atmospheric pressure at about 1011 \pm 1.2 Millibars (Inyang 1975; 1978). The Nsukka area comprises mainly of utisol which is characterized as low activity clays (Ezeaku 2006). The soil is well drained, prone to erosion and leaching losses of nutrients, hence of low fertility status. The vegetation is characteristically derived Savanna (Savanna-mosaic) agroecology, which represents different land uses such as forest, secondary forest, cultivated areas, and grazed grass pasture in a soil-landscape system (Ezeaku et al. 2015). The major characteristic of the vegetation of this area is the abundant combination of varied plant groups whose branches intertwine to form a continuous canopy of leaves. The major plant and grass species include Iroko, Palm tree, Obeche, Eupatorium Odoratum and imperatasylindrica (Uzoije et al. 2014).

\section{Materials and methods}

Groundwater potential of an area refers to the total amount of permanent water storage that exists in the aquifer, which is a function of its porosity and permeability. The groundwater potential $\Phi$, at any point, $\mathrm{P}$ in a porous medium is simply the hydraulic head, $h$ at the point multiplied by the acceleration due to gravity, $\Phi=$ gh (Freeze and Cherry 1979) or $\Phi=\mathrm{gz}$, where $\mathrm{g}=$ acceleration due to gravity and $\mathrm{z}=$ the topographic elevation of the water table at any point, (Toth). Since $g$ is very nearly constant in the vicinity of the earth's surface, $\Phi$ and $\mathrm{h}=\mathrm{z}$ is almost perfectly correlated. The hydraulic head, h, is therefore just as suitable as potential, $\Phi$. To recall Hubert's definition, it is a physical quantity, it is capable of measurement, and flow always occurs from regions where $h$ has higher values to regions where it has lower.

Understanding the static water level and its hydraulic head is pertinent to knowing its potential accessibility. The groundwater static water level refers to the level of groundwater in a well under normal, undisturbed, no-pumping conditions or depth of the water in a well under normal conditions. Static water level is best determined when the well has not been pumped for several hours prior to measuring. There are several ways to measure the static water level (ICRC 2011), which involves use of an electric sounder or electric depth gauge, wetted tape or an airline. The basic measurement for assessing groundwater is the depth of the water table in unconfined aquifers or the position of the piezometric surface in confined aquifers (Elizabeth 1994). On the other, dynamic groundwater level is the fluctuating water surface configuration resulting from recharge or withdrawals. Quantity and timing of precipitation are the greatest influencing factor on water-table fluctuations.

Hydraulic head or piezometric head can be defined as a precise measurement of a liquid pressure above a vertical datum, usually measured as liquid surface elevation and expressed in unit of length (metre or feet) at the bottom of a piezometer. It can be used to determine hydraulic gradient between two or more points.

The static water level data for the study were acquired from twenty-six (26) boreholes within the research area with the 
help of a Water Level Indicator, while their respective coordinates and elevations gotten by the use of a Global Positioning System (GPS) device. Water level indicator also called the dip tape is mechanically dropped into the borehole via unrolling its wireline and the electronic sensor touching the static groundwater surface signals with a beep sound. It is also used to indicate rate of recharge and discharge or yield of the aquifer. A Tape rule/Measuring tapes: a calibrated narrow band of woven fabric is used for the linear or depth measurement (Toth, J. (1963) and Snyder, D.T., 2008). This is used during a pumping test to measure the diameter of the borehole or container which is used to measure the discharge from the pump. A calibrated bucket was used to measure discharged water from the pump, and it is usually calibrated for accuracy. Timer or stop watch is used to measure time intervals during pumping test, and it is also a very important tool in pumping test as it gives time parameter for a pumping test analysis. Kerk Resistivity Meter (GeotechKerk Br) instrument also called Geotech Borehole Resistivity (BR) system, designed for logging shallow vertical wells, enables users to obtain the spontaneous potential (SP) curve. It is hand operated, and the logging is done by inserting the sensor or probe into the borehole and connecting the probe to the resistivity box to obtain data. Generator and power inverter were also essential in motorized pumping test because it serves as energy source that drives water from the subsurface to the surface. Submersible pumps drive groundwater from the subsurface through the aid of generators through discharge pipe to uplift or expel water which is pumped during the test.

\section{Geologic/Mud logging}

A technique providing well logs which are prepared by describing rock or soil cuttings brought to the surface by muds circulating in the borehole. It is a written record of the geological Formations of a borehole being drilled, according to depth and succession. It is a useful way of studying the Formational properties at each time interval, and it involves the study of drill samples gotten at each feet from the borehole. It gives the accurate record of time and depth required to obtain a particular lithology from the borehole. This technique involves the use of rotary drill bits so as to enable appropriate obtaining of samples. This sequential description of lithological samples gives the borehole drill log information such as change in lithological, characteristics and profile. More so, the mud log gives a local idea about the aquifer and the bearing Formation of the borehole.

\section{Borehole pumping test}

Pumping test is a technique for testing the performance of a pump or aquifer through continuous pumping of water. The aquifer properties are estimated from a constant-rate pumping test by fitting mathematical models to draw down data through a procedure known as curve matching. These mathematical models are used in identifying water flow regime and aquifer boundaries during a pumping test. For a successful pumping test, it is essential to record the flow rate throughout the test, although a constant pumping rate is most often the goal, but the rate of flow may vary during pumping test. The duration for pumping test is best made on the basis of hydrogeologic conditions at site and the objective of the test. Longer test may be necessary to estimate specific yield in a confined aquifer or to observe boundary effects. The main goal of performing a pumping test as a test of the aquifer is to estimate its hydraulic properties since it gives useful information about both the well and the aquifer, it can indicate whether the yield will be sufficient for an intended use or utility mostly by communities, factories, government agencies, etc. Borehole pumping test is done using the water level indicator also called the deep tape. It is best done when the water level has returned to normal after the well development, i.e. the well should have rested for at least $24 \mathrm{~h}$ after borehole development before carrying out the test. All the methods adopted in this research are mostly direct but fast as well as reliable and one of the best methods.

\section{Data collation, preparation and analysis}

The data collation for this research was done with the assistance from the Enugu State Water Corporation which incidentally documented record of boreholes pumping test of boreholes drilled under the Enugu/Anambra state Rural Water Supply Project between 1993 to present. Twenty-six boreholes static water levels data are analyzed, Table 1.

The hydraulic head was calculated using two parameters - the static water level and elevation in the relation: $H(m)=E(m)-S W L(m)$. where $\mathrm{H}$, water-table elevation; E, land-surface elevation and SWL, depth to water below land surface; m, metre (Snyder 2008). The modelling of DEM of the area, geologic and drainage/relief maps, regional flow net from cross section; static water level, hydraulic head and groundwater potential map of the area were done using Arc GIS, SURFER 11 and TCX converter.

\section{Results, interpretations and discussion}

Map models of static water level, hydraulic head, groundwater potential, digital elevation model (DEM) and a 3D surface model of the area have been constructed using results from borehole pumping test, elevation and geographic coordinate. These form thematic maps, weighed and ranked. These were interpolated and simulated in ArcGIS environment. The study area shows highly variable conditions for all the parameters which can be as a result of difference 
Table 1 Data showing locations, coordinate, elevation, static water level and hydraulic head

\begin{tabular}{|c|c|c|c|c|c|c|}
\hline Location & Town & Longitude & latitude & Elevation (m) & $\begin{array}{l}\text { Static water } \\
\text { level }(\mathrm{m})\end{array}$ & $\begin{array}{l}\text { Hydrau- } \\
\text { lic head } \\
(\mathrm{m})\end{array}$ \\
\hline L1 & Iheaka & $7^{\circ} 27^{\prime} 14.85^{\prime \prime}$ & $6^{\circ} 54^{\prime} 39.93^{\prime \prime}$ & 455 & 165.7 & 289.3 \\
\hline $\mathrm{L} 2$ & Umunko & $7^{\circ} 25^{\prime} 44.99^{\prime \prime}$ & $6^{\circ} 48^{\prime} 03$ & 455 & 184.3 & 270.7 \\
\hline L3 & Ekwegbe & $7^{\circ} 26^{\prime} 57.37^{\prime \prime}$ & $6^{\circ} 41^{\prime} 08.2^{\prime \prime}$ & 375 & 160.6 & 214.4 \\
\hline L4 & Iheakpu & $7^{\circ} 23^{\prime} 21.74^{\prime \prime}$ & $6^{\circ} 51^{\prime} 16.11^{\prime \prime}$ & 387.9 & 130.05 & 257.9 \\
\hline L5 & Umulumgbe & $7^{\circ} 25^{\prime} 18.76^{\prime \prime}$ & $6^{\circ} 36^{\prime} 14.18^{\prime \prime}$ & 434 & 180.6 & 253.4 \\
\hline L6 & Umuida & $7^{\circ} 23^{\prime} 41.99^{\prime \prime}$ & $6^{\circ} 58^{\prime} 58.8^{\prime \prime}$ & 316 & 103.05 & 212.6 \\
\hline L7 & Obimo & $7^{\circ} 19^{\prime} 27.7^{\prime \prime}$ & $6^{\circ} 48^{\prime} 23.18^{\prime \prime}$ & 301 & 66.6 & 234.4 \\
\hline L8 & Ohebe & $7^{\circ} 25^{\prime} 22.58^{\prime \prime}$ & $6^{\circ} 50^{\prime} 45.47^{\prime \prime}$ & 364 & 169.72 & 194.28 \\
\hline L9 & Nkalagu-obukpa & $7^{\circ} 19^{\prime} 28.47^{\prime \prime}$ & $6^{\circ} 56^{\prime} 42.6^{\prime \prime}$ & 363 & 139.25 & 223.8 \\
\hline L10 & Imufu & $7^{\circ} 26^{\prime} 17.04^{\prime \prime}$ & $7^{\circ} 00^{\prime} 01.56^{\prime \prime}$ & 366 & 114.6 & 251.4 \\
\hline L11 & Opi & $7^{\circ} 25^{\prime} 47.75^{\prime \prime}$ & $6^{\circ} 46^{\prime} 13.49^{\prime \prime}$ & 469 & 146.96 & 322.04 \\
\hline L12 & Nguru-Nsukka & $7^{\circ} 23^{\prime} 25.17^{\prime \prime}$ & $6^{\circ} 49^{\prime} 17.1^{\prime \prime}$ & 499 & 210.6 & 288.4 \\
\hline L13 & Obukpa-Nsukka & $7^{\circ} 24^{\prime} 03.5^{\prime \prime}$ & $6^{\circ} 53^{\prime} 22.93^{\prime \prime}$ & 413 & 124.8 & 271.8 \\
\hline L14 & Ozalla & $7^{\circ} 24^{\prime} 00.6^{\prime \prime}$ & $6^{\circ} 43^{\prime} 53.38^{\prime \prime}$ & 449 & 198.4 & 250.6 \\
\hline L15 & Ogrute & $7^{\circ} 24^{\prime} 29.87^{\prime \prime}$ & $6^{\circ} 51^{\prime} 52.16^{\prime \prime}$ & 413 & 141.23 & 271.77 \\
\hline L16 & Itchi & $7^{\circ} 21^{\prime} 00.12^{\prime \prime}$ & $6^{\circ} 57^{\prime} 59.18^{\prime \prime}$ & 309 & 120.6 & 188.4 \\
\hline L17 & Ibagwa Aka & $7^{\circ} 23^{\prime} 58.97^{\prime \prime}$ & $6^{\circ} 55^{\prime} 19.38^{\prime \prime}$ & 384 & 112.9 & 271.1 \\
\hline L18 & Umuna & $7^{\circ} 15^{\prime} 00$ & $5^{\circ} 46^{\prime} 00$ & 455 & 177.1 & 277.9 \\
\hline L19 & Edeoballa & $7^{\circ} 24^{\prime} 00.73^{\prime \prime}$ & $6^{\circ} 47^{\prime} 13.54^{\prime \prime}$ & 536 & 221.6 & 314.4 \\
\hline L20 & Edem & $7^{\circ} 20^{\prime} 51.27^{\prime \prime}$ & $6^{\circ} 51^{\prime} 59.39^{\prime \prime}$ & 427 & 169.2 & 257.8 \\
\hline L21 & Eha-Alumona & $7^{\circ} 27^{\prime} 15.4^{\prime \prime}$ & $6^{\circ} 48^{\prime} 54.27^{\prime \prime}$ & 477 & 146.48 & 328.5 \\
\hline L22 & Ovoko & $7^{\circ} 26^{\prime} 46.22^{\prime \prime}$ & $6^{\circ} 53^{\prime} 14.03^{\prime \prime}$ & 400 & 100.61 & 299.4 \\
\hline L23 & Obollo & $7^{\circ} 30^{\prime} 31.64^{\prime \prime}$ & $6^{\circ} 54^{\prime} 36.37^{\prime \prime}$ & 452 & 153.66 & 298.34 \\
\hline L24 & Ukehe & $7^{\circ} 24^{\prime} 20.37^{\prime \prime}$ & $6^{\circ} 38^{\prime} 27.25^{\prime \prime}$ & 375 & 91.46 & 283.54 \\
\hline L25 & Okpuje & $7^{\circ} 17^{\prime} 32.01^{\prime \prime}$ & $6^{\circ} 54^{\prime} 09.7^{\prime \prime}$ & 251 & 68.9 & 182.1 \\
\hline L26 & Akpakume & $7^{\circ} 17^{\prime} 19.38^{\prime \prime}$ & $6^{\circ} 39^{\prime} 09.8^{\prime \prime}$ & 264 & 82 & 186 \\
\hline
\end{tabular}

in geomorphology, elevations and structural differences. Results of the mud logging indicate five geologic formations zoning, Table 2. According to the subdivisions above, it can be deduced that the Ajali Sandstone Formation is the major Formation with groundwater potential in the study area, while Mamu and Nsukka Formation serves as the confining formations. Below are figures of the results of various criterion model maps of the study (Figs. 3, 4, 5, 6, 7).

Result of the static water level model shows variations in the static water levels across the study area. However, the topographic elevation of the water table is generally similar in form to the land surface. In the northwestern through central part, and towards northeastern to southeastern parts of the research area (i.e. Northwest of Obukpa, Nsukka, EhaAlumona, Obolo and Umulumgbe) which is underlain by Ajali and Nsukka Formation, shows a fair variation with higher values in the static water level ranges of about 220$150 \mathrm{~m}$ with an average of about $185 \mathrm{~m}$. The Southern part through southwestern to northwestern up to northern parts comprising of Ukehe, Aku, Okpujeupto Enugu Ezike has higher variations but low values in the static water level
Table 2 Geologic Formation area occurrence

\begin{tabular}{lll}
\hline Area & Geologic Formations & $\begin{array}{l}\text { Static water } \\
\text { level value range } \\
(\mathrm{m})\end{array}$ \\
\hline North central & Ajali and Nsukka Formation & $220-150$ \\
Southwestern & Ajali and Nsukka Formation & $70-180$ \\
Southeastern & Ajali and Mamu Formation & $120-210$ \\
Northwestern & Ajali and Nsukka Formation & $70-180$ \\
Northeastern & Ajali Formation & $90-180$ \\
\hline
\end{tabular}

values with areas around Ukehe having the lowest value of $70-130 \mathrm{~m}$, while the value range varies from 70 to $150 \mathrm{~m}$. Obimo area to Ozara in the Southwest to South of Nsukka has high variation and high value of static water levels.

Hydraulic head model map of the area shows central part of the study area comprising Nsukka and Edem has moderately to high head values. Northeastern area of the study area comprising S/E of Nsukka to Obollo through Ehalumona has the highest hydraulic head values ranging from 308 to $324 \mathrm{~m}$. The 


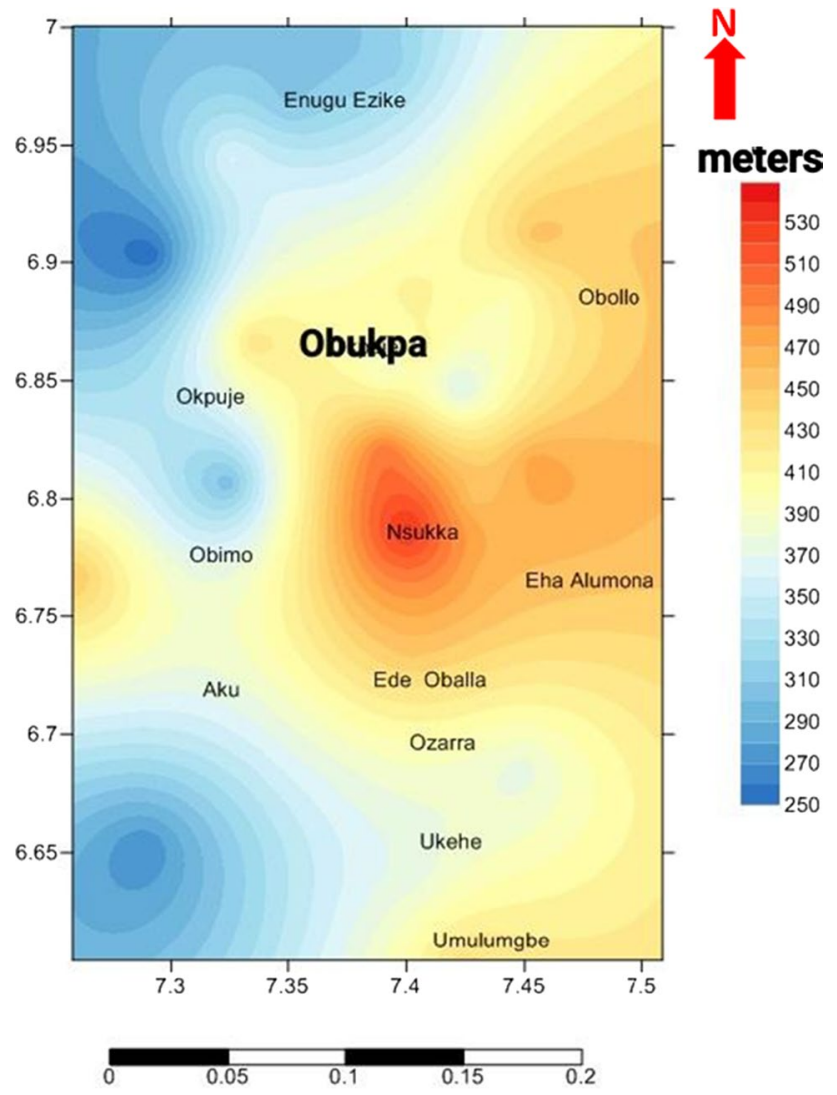

Fig. 3 Digital elevation model map of the study area
Northwestern (west of Enugu Ezike) through Western (Okpuje) to the Southwestern part (southern Aku) and Southeastern (Ozarra central) shows lowest to low head values, ranging progressively from 180 to $244 \mathrm{~m}$. North central (east of Enugu Ezike) through Central area (west of Obukpa, Okpuje, Obimo, west of Ede Oballa) to Southern area (Ukehe, Umulumgbe) fall within moderate head values ranging between 236 and $268 \mathrm{~m}$. Following the above, the model has categorized the area into five hydraulic head regions, Table 3.

In view of the above, the study area shows a maximum hydraulic pressure towards the Northeast, moderate around the Central region and minimum hydraulic pressure towards the extreme Northwestern and Southwestern parts of the study area. The result of the groundwater potential model Fig. 7 reveals that the Central region has the highest groundwater potential. There is progressive variation from moderate to low groundwater potential values from extreme North central towards the Northeastern part of the study area. The Southeastern part is characterized by moderate to high groundwater potential values towards the central part of the study area around Nsukka, while the Southwestern part is characterized by very low to moderately low groundwater potential around Obimo with a slight increase in groundwater potential around parts trending to the central part of the study area and at the extreme end of Southeastern part of the map. Some areas within northwestern part of the area are characterized by very low groundwater potential (areas

Fig. 4 3D surface flow model of the study area
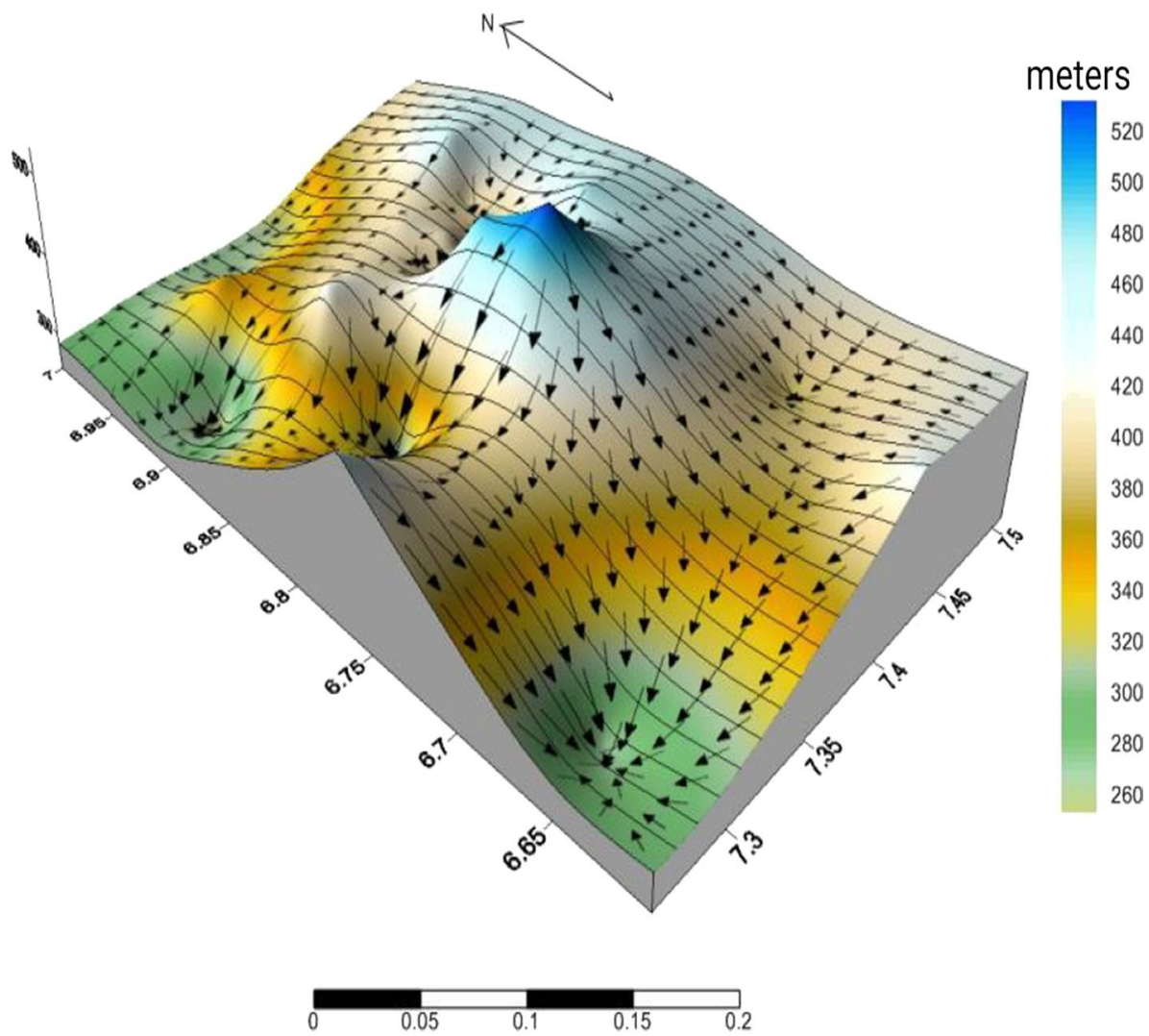


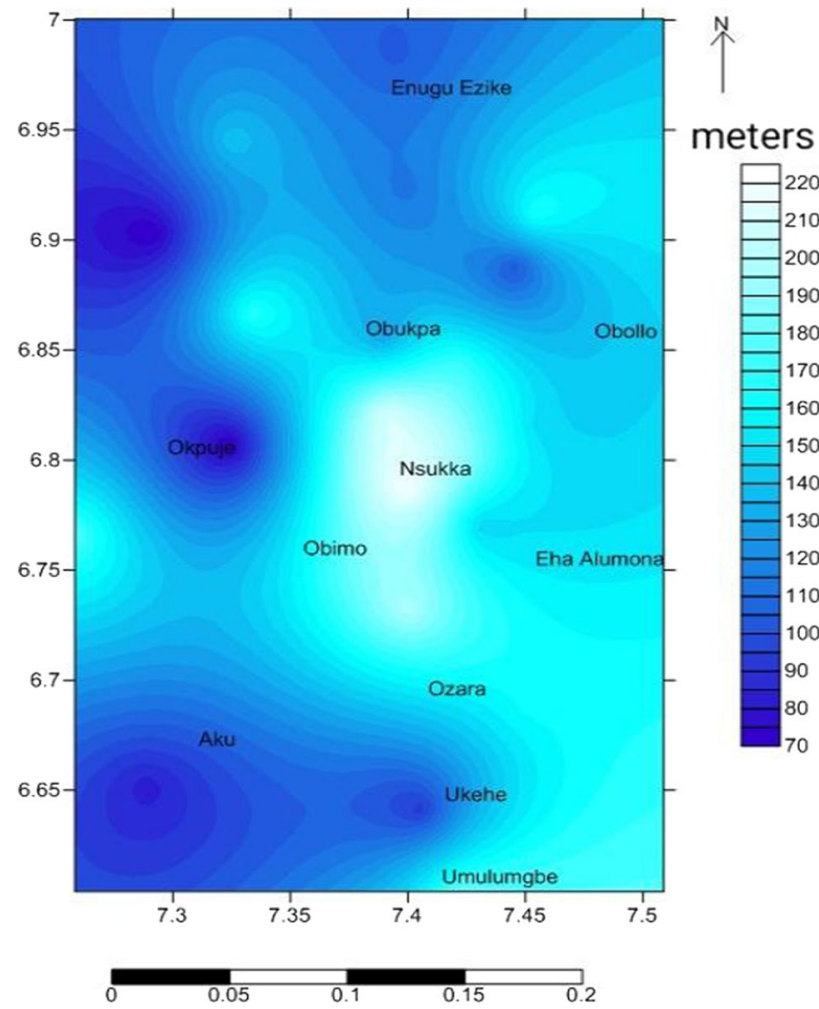

Fig. 5 Static water level map model of the study area

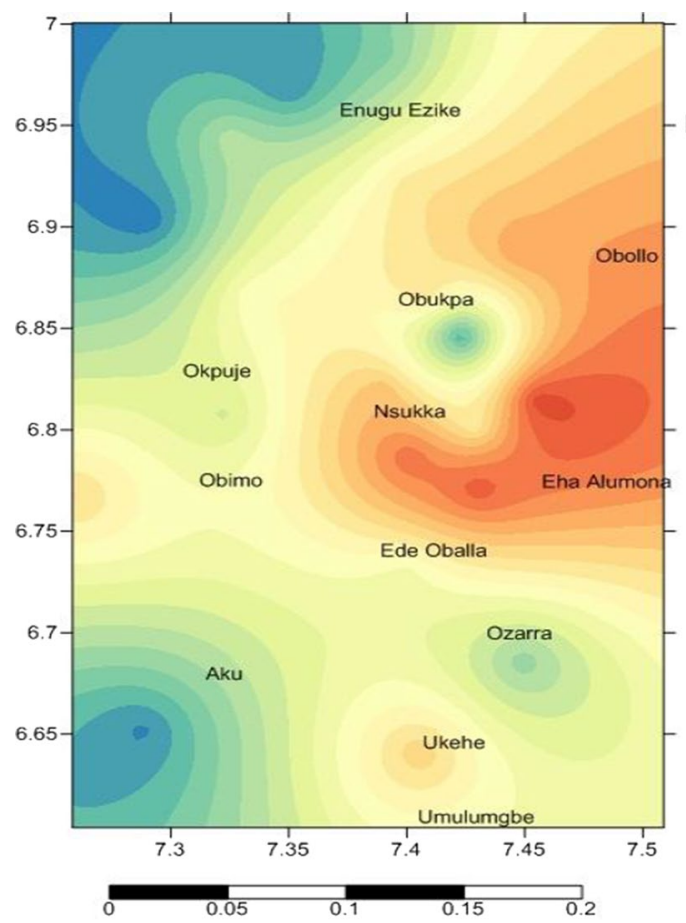

Fig. 6 Hydraulic head map model of the study area between Okpuje and Obimo) and also show similar trend across the whole northwest in parts around Enugu-ezike with low values and very low towards upper part of Okpuje, Table 4.

\section{Limitations}

The ArcGIS software used in the judgement is not a decision-making. The decision is primarily on techniques and human judgements; hence, the researcher should have a good judgement expertise before using GIS. Environmental variables such as temperature, humidity, pressure, gravity, elevation, and vibration can impact on the measurement result. We do not report an excessive number of digits and round measurement uncertainty to two significant figures.

\section{Conclusion}

This study aimed at assessing the groundwater potential of Nsukka and environs considering the effect of groundwater potential to factor of safety. This was achieved by integration of elevation, static water level and hydraulic head to delineate groundwater potential of Nsukka and environs employing GIS capability approach. Superimposing the DEM, hydraulic head model over the static water level

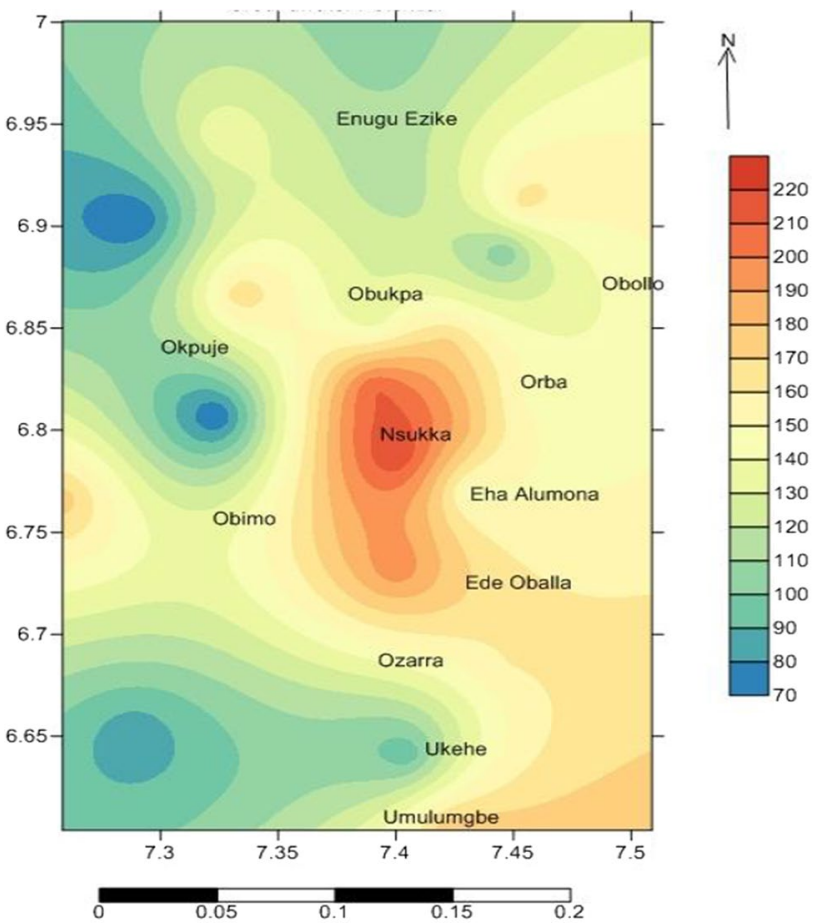

Fig. 7 Groundwater potential map model of the study area 
Table 3 Hydraulic head regions categorization

\begin{tabular}{ll}
\hline Hydraulic head distribution & Region \\
\hline Very low to low head values & Northwestern and Southwestern part \\
Low to Moderate head values & west of North central, Central to Southern part \\
Moderate to high head values & North central, Central to Southern part \\
Moderately high to high head values & east of North central, Central to east of N/E part \\
High to very high head values & Northeastern part \\
\hline
\end{tabular}

Table 4 Groundwater potential of the area

\begin{tabular}{lll}
\hline Region & Groundwater potential & Value range \\
\hline Central part & Very high & $220-200$ \\
Southeastern part & high & $190-170$ \\
Northeastern part & Moderate & $160-140$ \\
Southwestern part & Low & $130-100$ \\
Northwestern part & Very low & $90-70$ \\
\hline
\end{tabular}

produced the groundwater potential model map of the area properly delineated for different development purposes to avoid mismatches and the consequent distress in livelihood. This reveals Central region of the study area has the highest groundwater potential in places around Nsukka and Edem alongside with Southeastern portion comprising of Ozarra and Ede-Oballa. These areas can yield enough of groundwater adequate to serve its resident population. The Northwestern region has the lowest groundwater potential in places around Ukehe and Aku alongside with Northwestern portion around Okpuje and can pose difficult groundwater provision and distress to livelihood.

This study showed that static water level and hydraulic heads play an important role in delineating zones with high and low groundwater potential and fairly follow elevation/ topography. Further, the use of GIS is a powerful tool to improve and aid effective as well as develop sustainable groundwater management strategy. However, the interpretation and use of model output should be done with limitations of interpolation in perspective.

Author contributions All authors contributed to the study conception and design. Material preparation, data collection and analysis were performed by (Onwe, Mkpuma Rock), (Ngwu Tochukwu Ambrose), (Ema Michael Abraham) and (Osibe Kingsley Osike). The first draft of the manuscript was written by (Onwe, Mkpuma Rock) and all authors commented on previous versions of the manuscript. All authors read and approved the final manuscript.

Funding No external funding. Research funded by Authors.

\section{Declarations}

Conflict of interest The authors declare that we have no conflict of interest.
Open Access This article is licensed under a Creative Commons Attribution 4.0 International License, which permits use, sharing, adaptation, distribution and reproduction in any medium or format, as long as you give appropriate credit to the original author(s) and the source, provide a link to the Creative Commons licence, and indicate if changes were made. The images or other third party material in this article are included in the article's Creative Commons licence, unless indicated otherwise in a credit line to the material. If material is not included in the article's Creative Commons licence and your intended use is not permitted by statutory regulation or exceeds the permitted use, you will need to obtain permission directly from the copyright holder. To view a copy of this licence, visit http://creativecommons.org/licenses/by/4.0/.

\section{References}

Adepelumi AA, Akinmade OB, Fayemi O (2013) Evaluation of groundwater potential of Baikin ondo state Nigeria using resistivity and magnetic techniques: a case study. Univ J Geosci 1(2):37-45. https://doi.org/10.13189/ujg.2013.010201

Agagu OK, Fayose EA, Paters SW (1985) Stratigraphy and sedimentation in the cenonian anambra basin of Eastern Nigeria. J Min Geol 2:25-35

Akbas F (2014) Spatial variability of soil color parameters and soil properties in an alluvial soil. Afr J Agric Res 9:1025-1035. https://doi.org/10.5897/AJAR2013.8316

Amah JI, Okoye EI, Onwuka S (2016) Statistical modeling of hydrostratigraphic and hydraulics of Cretaceous aquifers in Nsukka, North of Anambra Basin, Southeastern Nigeria. Adv Appl Sci Res 7(4):32-41

Anukam LC (1997) Water pollution control-a guide to the use of water quality management principles case study IV-Nigeria. E \& F. Spon on behalf of WHO/UNEP

Ezeaku PI (2006) Estimation of crop water requirement from climate and soil data for field maize production in southeastern Nigeria. J Sustain Trop Agric Res 17:91-96

Ezeaku PI, Eze FU, Oku E (2015) Profile distribution and degradation of soil properties of an ultisol in Nsukka semi-humid area of Nigeria. Afr J Agric Res 10(11):1306-1311

Ezeh CC, Ugwu GZ (2010) Geoelectrical sounding for estimating groundwater potential in Nsukka LGA Enugu State, Nigeria. Int J Phys Sci 5(5):415-420

Ezeigbo HI, Ozioko DC (1987) Towards efficient rural-water supply to Nsukka area and environs. In: Proceeding of 2nd NISWASAsymposium Lagos

Ezim OE, Obiadi II, Akaegbobi MI (2017) The use of statistical grainsize method in analysing borehole and evaluating aquifer parameters. A case study of Ajali sandstone formation, Southeastern Nigeria. Global J Geol Sci 15:77-92. https://doi.org/10.4314/gjgs. v15i1.7

Freeze RA, Cherry JA (1979) Groundwater. Prentice Hall, Englewood Cliffs 
Ibeh CU (2020) Effect of changing groundwater level on shallow landslide at the basin scale: a case study in the Odo basin of south eastern Nigeria. J Afr Earth Sci 165:103773

International Committee of the Red Cross (ICRC) (2011) Technical review practical guidelines for test Pumping in water wells

Iňigo A, Alonso-Martirena JI, Marín A, Jiménez-Ballesta R (2012) Soil property variability in a humid natural Mediterranean environment: La Rioja, Spain. Span J Soil Sci 2:38-54

Inyang PCB (1975) Climatic regions of Nigeria in maps. Ethopia Publishing Company, Benin, pp 1-30

Kaur L, Rishi MS (2018) Integrated geospatial, geostatistical, and remote-sensing approach to estimate groundwater level in Northwestern India. Environ Earth Sci 77:786. https://doi.org/10.1007/ s12665-018-7971-8

Kaur L, Rishi MS, Singh G, Thakur SN (2020) Groundwater potential assessment of an alluvial aquifer in Yamuna sub-basin (Panipat region) using remote sensing and GIS techniques in conjunction with analytical hierarchy process (AHP) and catastrophe theory (CT). Ecol Indicat 110:105850

Ladipo KO (1986) Tidal shelf depositional model for intertidal sandstone, Anambra Basin, Southern Nigeria. J Afr Earth Sci $5: 177-185$

Ladipo KO, Nwajide CS, Akande SO (1992) Cretaceous and paleogene sequences in the Abakaliki and Anambra Basins, Southeastern Nigeria. In: International symposium on geology of deltas, Port Harcourt

Liu DW, Wang ZM, Zhang B, Song KS, Li XY, Li JP, Li F, Duan HT (2006) Spatial distribution of soil organic carbon and analysis of related factors in croplands of the black soil region, Northeast China. Agric Ecosyst Environ 113:73-81. https://doi.org/10. 1016/j.agee.2005.09.006

lnyang EB (1978) 'l'heClmate of Nsukka and Environs. In: Ofomata GEX (ed) Ln the Nsukka environment. Fourth Dimension Publishers, Nigeria, pp 86-97

Mamah LI, Ekine AS (1989) Electrical resistivity anisotropy and Tectonism in basal Nsukka formation. J Min Geol 25:121-129

Nwajide CS (2006) Anambra Basin of Nigeria: synoptic basin analysis as a basis for evaluating its hydrocarbon prospectively. In: Okogbue $\mathrm{CO}$ (ed) Hydrocarbon potentials of the anambra basin: geology, geochemistry and geohistory perspectives. Proceedings of the first seminar organized by the petroleum technology development fund (PTDF) Chair in Geology, University of Nigeria, Nsukka, May 12-15, 2005, pp 1-46

Nwankwor GI, Okeke OC, Ahiarakwem CA (2004) Land capability index mapping of Enugu area and environs for residential land use option. AdvGeosci 2(1):54-64

Obi GC, Okogbue CO, Nwajide CS (2001) Evolution of the Enugu Cuesta: a tectonically driven erosional process. Glob J Pure Appl Sci 7:321-330

Obi GC (2000) Depositional model for the Campanian-Maastrichtian Anambra Basin, Southern Nigeria. Ph.D. Thesis, University of Nigeria, Nsukka

Ofomata GEK (1967) Landforms on the Nsukka Plateau of Eastern Nigeria. Nig Geol 1(10):3-9
Onunkwo AA, Uzoije AP, Onyekuru SO (2011) Application of geographic information system (GIS) in industrial land capability index mapping of a developing country: a case study of Enugu area, South-Eastern Nigeria. Int J Curr Res 3(8):100-105

Onwe MR, Agbi I, Chukwu CG (2017) Effects of geostructural features on the quality and quantity of groundwater in Abakaliki area and environs. Int J Interdiscip Res Innov 5(4):99-108

Onwe MR, Nwankwo GI, Ema MA, Emberga TT (2018) A geographic information system (GIS) based land suitability analysis and characterization for industrial siting in Abakaliki area Southeastern Nigeria. Int J Dev Res 08(05):20206-20209

Onwe MR, NwankworG I, AhiarakwemC A, Abraham EM, Emberga TT (2019) Assessment of geospatial capability index for siting waste dump/landfill to control groundwater geopollution using geographic information system (GIS) approach: case study of Abakaliki area and environs, Southeastern Nigeria. Appl Water Sci 10:12. https://doi.org/10.1007/s13201-019-1087-5

Onwuemesi AG (1990) Hydrogeophysical and geotechnical investigation of the Ajali Sandstone in Nsukka and environs with reference to groundwater resources and gully erosion problems: water resources. J NAH 2(1):70-76

Ozoko DC (1996) Hydrogeology of Nsukka Area and Environs, Anambra State Nigeria Unpublished M.Sc Thesis, University of Nigeria

Reyment RA (1965) Aspect of the geology of Nigeria. Ibadan University Press

Shaw EM (1994) Hydrology in practice, 3rd edn. Taylor \& Francis e-Library, ISBN 0-203-01325-5

Singh LK, Jha MK, Chowdary VM (2018) Assessing the accuracy of GIS-based multi-criteria decision analysis approaches for mapping groundwater potential. Ecol Indicat 91:24-37

Snyder DT (2008) Estimated depth to ground water and configuration of the water table in the Portland, Oregon area: U.S. Geological Survey Scientific Investigations Report 2008-5059. (Available at http://pubs.usgs.gov/sir/2008/5059/)

Thapa R, Gupta S, Gupta A, Reddy DV, Kaur H (2018) Use of geospatial technology for delineating groundwater potential zones with an emphasis on water-table analysis in Dwarka River basin, Birbhum, India. Hydrogeol J 26:899-922

Toth J (1963) A theoretical analysis of groundwater flow in small drainage basins. J Geophys Res 68(16):4795-4812. https://doi.org/10. 1029/JZ068i016p04795

Ugwuanyi MC, Ibuot JC, Obiora DN (2015) Hydrogeophysical study of aquifer characteristics in some parts of Nsukka and Igboeze south local government areas of Enugu State Nigeria. Int J Phys Sci 10(15):425-435

Uzoegbu UM, Uchebo UA, Okafor I (2013) Lithostratigraphy of the Maastrichtian Nsukka formation in the Anambra Basin, SE Nigeria. J Environ Sci Toxicol Food Technol 5(5):96-102

Uzoije AP, Onunkwo AA, Ibeneme SI, Obioha EY (2014) Hydrogeology of Nsukka Southeastern Nigeria: a preliminary approach to water resources development. Am J Eng Res 3(1):150-162 